\title{
Tertiary students' understandings and practices of informal learning: A New Zealand case study
}

\author{
Kwok-Wing Lai and Lee A. Smith \\ University of Otago, Dunedin, New Zealand
}

\begin{abstract}
In 2013, we undertook research in a New Zealand University to gain insights into students' understandings of informal learning, its connection to formal learning and how they engaged in informal learning using digital and mobile technologies. A total of 765 students (postgraduate, undergraduate and first-year students) completed a questionnaire. Follow-up interviews were conducted with 30 of these students. A total of $90 \%$ of the questionnaire participants undertook informal learning to support their formal learning or for their personal development. The undergraduate and first-year interview participants reported that they primarily engaged in informal learning to support their formal coursework. However, the postgraduate participants made arbitrary links between their informal learning and formal learning. The three groups of participants used the same digital technologies to engage in informal learning, including laptops, desktop computers and mobile phones, while the dominant means of conducting informal learning was accessing the Internet and using online tools such as Google and Wikipedia. Fewer students used social networking sites (such as Facebook or Twitter) or mobile digital technologies (such as iPads and tablets) for informal learning.
\end{abstract}

\section{Introduction}

People learn informally through a variety of means. Since the 1990s, the increasing availability of digital and mobile technologies has meant that we now have unlimited access to information, which in turn creates many learning opportunities (Mills, Knezek, \& Khaddage, 2014). These learning opportunities have the potential to change the nature of learning and also how informal learning can be undertaken to support formal studies (Hall, 2009). These networking opportunities can also facilitate more interactive and collaborative learning opportunities, which are drastically different from the informal learning that occurs through more traditional means such as reading books or watching television.

Formal learning and informal learning have traditionally been viewed as two distinct forms of learning, distinguished on the basis of learning content, and by where, when and how learning occurs. For instance, formal learning is associated with a formal course and often leads to a qualification, whereas informal learning is traditionally defined as interest driven and occurring incidentally (Dabbagh \& Kitsantas, 2012; Hall, 2009). Further, formal learning occurs in an educational institution (such as a university) during official course time, while informal learning is often done in one's own time, in settings such as one's home or flat, or through participation in various social/sports groups (Dabbagh \& Kitsantas, 2012; Hall, 2009; Sefton-Green, 2004). Formal learning is usually guided by a teacher, whereas informal learning is primarily self-directed and learner-centred (Bousted et al., 2011; Lai, Khaddage, \& Knezek, 2013). As a consequence of the increasing popularity of digital and mobile technologies such a distinction between informal and formal learning may now be considered irrelevant (Hall, 2009). For example, students can do formal work outside of university on their mobile devices or can undertake informal learning at university using their mobile devices.

Furthermore, Barron (2006) and Cross (2007) have both argued that formal and informal learning are two points on a continuum, rather than two opposing categories. In this paper, we also conceptualise formal and informal learning as two points on a "continuum of learning” (Cross, 2007, p. 16). We also perceive that the degree in which learning can be considered formal or informal is dependent on the extent that the learners can control their learning process (Furlong \& Davies, 2012). For instance, learning can be considered informal if learners choose the content and when and where they learn and whom they learn with. If students undertake informal learning to support their coursework, we still consider this as informal, as long as they can exercise agency in their learning and their learning is not prescribed coursework. 


\section{Why study informal learning?}

There are several reasons why the study of informal learning practices is important. Many people spend considerable time surfing the Internet for information. For instance, Livingstone (2009) compares the results of two Canadian national studies (undertaken in 1998 and 2004), which focused on adults' education levels and their patterns of informal learning. He found that on average participants (he does not list the number) aged 18-24 spent 17 hours per week on informal learning tasks relating to their interests. Nowadays, many people also engage in social networking communication with their peers using Web 2.0 applications such as Facebook or Twitter, which have considerable learning potential (Song \& Lee, 2014). However, little is known about whether people use online networking to connect informal and formal learning.

Digital and mobile technologies provide informal learning opportunities to many people (Khaddage et al., 2015; Mills et al., 2014). For example, Bonk (2012) lists over 300 informal learning websites that can be used to augment formal learning. Although Web 2.0 applications and mobile technologies are being used to support learning in schools (e.g., Clough, Jones, McAndrew, \& Scanlon, 2009; Song \& Lee, 2014) and higher education settings (e.g., Dabbagh \& Kitsantis, 2012; Lai \& Hong, 2014), many teachers still consider informal learning as unrelated to the formal curriculum. A better understanding of students' informal learning practices may enable teachers to build connections between the two forms of learning.

However, bridging formal and informal learning through incorporating Web 2.0 tools in educational settings as well as using social networking sites for informal learning is not straightforward. Students may not want to use these technologies in their formal learning because they want to distinguish between their home and school/university lives (see Crook, 2012; Selwyn, 2011. For example, in an Educause survey of 10,000 undergraduate students in the United States, Dahlstrom, Walker, and Dziuban (2013) found that $75 \%$ of the participants reported owning a smartphone, but $60 \%$ also said they wanted to keep their private and academic lives separate.

In a study of the mobile-learning literacy of South African university students, all 18 participants stated that mobile literacy is necessary for educational success and employment (Bosman \& Strydom, 2016). They also said that as most tertiary students own a mobile device they can easily operate them. However, currently, we have little information on how mobile devices can be used to bridge or synthesize informal and formal learning (Khaddage et al., 2015; Lai et al., 2013). One possible reason for this is the lack of communication between researchers working in the fields of informal and formal learning, which in turn means that information on informal learning cannot easily be "translated into formats that can be employed within school [and tertiary educational] settings” (Bull et al., 2008, p. 103). Further research is needed to gather information on students' understandings of the learning opportunities afforded by digital and mobile devices and whether they take up these opportunities.

\section{The study}

In 2013, we conducted a study in a research-intensive New Zealand university, which aimed to gather information on how students understood informal learning, the relationship between formal (in face-toface lectures or tutorials) and informal learning and how the students used digital and mobile technologies to support their informal learning. We also aimed to explore if there were any differences in the understandings of recent high school graduates who completed high school in 2012 and were embarking on their first-year of university (FY), undergraduates (who may have been first-year students but did not come directly to university from high school) (UG) and postgraduate students (PG) who participated in the study. The purpose of this research was to develop understanding of how formal and informal learning can be connected and to provide insights on how pedagogical practices can be designed to bridge these two forms of learning. The following research questions guided the study:

(1) How do students understand the nature of informal learning and perceive its relationship with formal learning?

(2) How do students engage in informal learning and what methods do they use?

(3) What digital and mobile technologies do students use to support informal learning? 


\section{Methodology}

Qualitative and quantitative methods of data collection were employed in the study. A quantitative paperbased questionnaire was developed, which included questions relating to digital learner characteristics identified by Bullen, Morgan, and Qayyum (2011). The statistical package SPSS was used to aid data analysis. In order to gain more detailed information on the participants' understanding of informal learning and the relationship between informal learning and formal learning, semi-structured interviews were conducted with 30 questionnaire participants who volunteered to be interviewed. The interview schedule contained questions adapted from Rohs's (2008) research on informal learning and related to how the participants understood informal learning and the relationship between informal learning and their formal courses. An inductive analysis of the interview data was undertaken using a version of the constant comparative method of data analysis (Maykut \& Morehouse, 1994). Themes were identified in the data, and NVivo was used for coding excerpts that reflected these themes (Maykut \& Morehouse, 1994). However, the research questions and prior reading in the field also influenced the thematic analysis.

Ethics approval was obtained from the relevant Ethics Committee in 2012. In the first academic semester of 2013, six postgraduate students were employed to approach students (from the four academic disciplines at the university, humanities, health sciences, science and commerce) while they waited in line for course approval, where they asked them if they would like to fill in the questionnaire. Course approval is a procedure where lecturers ensure that students have enrolled for the correct courses in an undergraduate degree and that students have no timetable clashes. Postgraduate course enrolment is primarily done online, however; and therefore, all the postgraduate student offices in the university were visited. Postgraduate students were personally invited to complete the questionnaire. On the questionnaire respondents were also invited to participate in a follow-up interview (either by telephone or face-to-face).

A total of 813 students completed the questionnaire, but due to incomplete or non-valid responses only 768 questionnaires were included in the final analysis. Of the 768 students who completed the questionnaires, 240 were first-year students, 415 were undergraduate students and 113 were postgraduate students. Of the 30 student interview participants, six were first-year students, 12 were undergraduate students and 12 were postgraduate students. Both the questionnaire and interview samples were convenience samples.

It should be explained that New Zealand has a relatively high rate of tertiary participation, with approximately 55\% of young people (aged 25 to 34 years) graduating from a tertiary institution in 2013 (Organisation for Economic Co-operation and Development, n.d.). As a consequence of numerous neoliberal reforms implemented during the 1990s and following decades, New Zealand also has a user-pays tertiary education sector (Small, 2009). Student loans were introduced in the 1990s, and tertiary fees increased significantly during this decade based on the notion that people act to maximize their selfinterest and education increases one's life chances (Humpage, 2015). All students can apply for a student loan to cover their course-related costs (maximum of $\$ 1000$ annually) and tertiary fees; however, this money must be repaid post-graduation. Students with parents whose income is below the threshold can also apply for a student allowance, which pays daily living costs and does not have to be repaid after graduation. Students whose parents earn above the threshold can apply for living costs, which have to be repaid post-graduation (Ministry of Social Development, n.d.).

\section{Findings}

\section{Participants' understandings of informal learning}

Based on the definition of informal leaning we used in the study (as explained previously), the overwhelming majority (90\%) of the questionnaire participants reported that they had engaged in informal learning activities in the previous year. The majority (72\%) also undertook informal learning to enhance their formal studies and for their personal development. However, 6\% stated that they only engaged in informal learning to enhance their formal learning, while 22\% reported that they undertook informal learning solely for their personal development. Chi-square tests were conducted to investigate if there were any group differences and none were found. 
When the interview participants were asked for their understandings of informal learning, the majority (28 from 30) drew on traditional definitions of informal learning. For instance, they stated that informal learning occurred outside a formal educational setting in spaces like libraries, their home or flat, as well as through talking with friends and searching the Internet. All of the interview participants drew on traditional definitions of informal learning. For instance, informal learning was something they said that they did in their own "private time” (PG3), or "off your own back in your own time” (UG6). The majority of interview participants (28 from 30) also stated that informal learning is self-directed, motivated by personal interests and done independently without the guidance of a teacher/lecturer. For example, PG10 commented that informal learning was what "I do everyday to learn things for my own purposes ... it could be something like just self-learning ... in my own way with my own timing, and my own resources”.

While 28 interview participants considered informal learning as self-directed, there were differences between the three groups of participants. The majority of postgraduate participants (11 from 12) made a distinction between informal learning and formal studies since they were undertaken for different purposes. For example, PG 10 said:

Informal learning has to do with learning for life, and the formal one I see more as ... you learn in order to you know get a job later ... but informal learning is more aligned with that free part of yourself that you learn about the things that you want.

One postgraduate student did link informal learning with her formal coursework, however, stating that informal learning consisted of "group work or assignments or PowerPoint slides or something” (PG6). The other 11 postgraduate students reported informal learning was primarily done for "personal interest" (PG10) and was not "something you learn in order to get a job" (PG1). They also stated that informal learning happens incidentally; for instance, informal learning "happens as a matter of course in the things that you do and the life that you live” (PG8). When asked for examples of the informal learning undertaken in their own lives, PG3 said, "I like to look into cooking books for example, about cheese making ... I look something up for gardening or we renovated the house, renovating techniques or something ... not as a project as such, just more learning”.

All of the postgraduate participants (with the exception of PG6) made comments suggesting that informal learning was useful for supporting formal learning in an abstract manner. They also explained that informal learning related to real-life situations and was done for the purpose of self-improvement or for interest. The link between informal learning and their formal coursework did not emerge as a dominant theme in the postgraduate participants' accounts.

The 12 undergraduate participants were asked whether they thought their informal learning augmented their formal coursework. Although one undergraduate student (UG6) did distinguish informal learning from formal learning, the remaining 11 made similar comments that linked informal learning to their formal learning and also explained that it was something they did for personal interest. For instance:

I mean even if it doesn't explicitly connect to something you're learning about through formal education ... just the idea of being interested in learning for the sake of finding something out definitely sort of bodes well for being able to learn something in a formal setting. (UG1)

UG7 gave an example of how informal learning was used to augment his formal education:

I did Statistics, which I've always had a mental block of mathematics of any sort, so I remember last year Googling different statistical equations, and methods, and principles that I was getting in the lecture that I wasn't grasping properly ... so that added to my ability to understand the information I was being given.

At the same time, he also reported how people engaged in everyday informal learning for their own personal development: 
Well I think we learn something everyday in smaller ways, if you're talking about a specific interest, if someone has a specific interest in learning something, that's not something that would happen everyday, but that you know we learn small pieces of information everyday. (UG7)

The first-year participants considered informal learning as more flexible than their formal coursework, and also stated that it was not a requirement of formal studies. Nevertheless, five of the six participants reported that they engaged in informal learning with the direct intention of augmenting their formal education. For instance, FY5 said that informal learning "is something you do of your own free will and it's a choice that you do to supplement your [formal] learning”. In other words, even though the first-year students felt that they had control over their informal learning, it was still tied to their formal learning experiences. For instance, FY3 said he did informal learning "to supplement things I'm learning at university, or I used to when I was at school”. When asked why he did informal learning FY4 explained that "Formal education is pretty much in class and then the informal learning would be sort of ... outside so you still part of that formal environment using the same teacher but sort of in your own time it's a bit extra”. And he gave an example:

The last year of high school, I found physics quite difficult so we'd get in groups 'cause a lot of people in the class struggled, and so we all got together and just sort of solidified everything and made sure we understood it. We had one person in the group who really did understand it and so we could just ask them for help.

Although the interview participants drew on traditional understandings of informal learning being undertaken in one's free time, driven by interest and occurring incidentally, there were significant differences in the way the three groups connected informal learning to their formal learning. The majority of postgraduate students (11 from 12) connected informal learning to their formal coursework in an abstract manner, while the majority of undergraduate (11 from 12) and first-year students (five from six) made direct links between informal learning and their formal coursework.

\section{The relationship between formal and informal learning}

Although most interview participants (25) made comments that highlighted how they had a pragmatic view of how informal learning related to their formal studies, that is as supporting their coursework, five participants' commented how they saw informal and formal learning as interconnected and inseparable. For instance:

It's quite like a symbiotic relationship. I don't think I would look at some of the articles I do for my informal reading now the same way after I've learned about how to look at them through my formal learning ... [For example] I do get passionate about psychology ... but it was working for [names organisation] and doing my own reading outside of university and getting involved in politics ... that's really shaping what my actual study for my $\mathrm{PhD}$ is. (PG7)

I think they go together ... the subject matter of most formal learning is part of our everyday experience, so you can find it in informal settings, as well as it's just sort of a broadening or more adding to the knowledge that you have, and I think that informal learning plays a decent role in that. (UG7)

Two interview participants also made comments highlighting how they saw the relationship between formal and informal learning as complementary, which supports Greenhow and Robelia's (2009) assertion. These participants stated that what was learned formally could motivate informal learning outside a formal institution. For example:

I think the formal learning, well personally gives me a bit of a drive to go out and find more, not only that the informal learning would be more reason to turn up to the formal ... they sort of push each other up higher in terms of importance. (UG5)

It should also be noted, however, that two interview participants stated that it was difficult to make a distinction between formal and informal learning because it is "very hard to tease out what is informal 
and what is formal learning” (PG7). PG8 also said that making a distinction between informal and formal learning might reinforce the general understanding that "real” learning only occurs in formal institutions.

\section{How did participants engage in informal learning?}

The second research question was: how do students go about informal learning and what methods do they use? The most popular informal learning methods participants used both for undertaking informal learning for personal development and to support their studies was through searching the Internet, conversing with friends and reading books (see Table 1). No significant differences were found between the participant groups.

Table 1

Methods to undertake informal learning

\begin{tabular}{|c|c|c|c|c|}
\hline & $\begin{array}{l}\text { To enhance } \\
\text { university/school } \\
\text { work }(n=535)\end{array}$ & $\begin{array}{l}\text { Chi-square test } \\
\text { for group } \\
\text { differences }\end{array}$ & $\begin{array}{l}\text { For } \\
\text { personal } \\
\text { development } \\
(n=648)\end{array}$ & $\begin{array}{l}\text { Chi square test } \\
\text { for group } \\
\text { differences }\end{array}$ \\
\hline $\begin{array}{l}\text { Through the } \\
\text { Internet }\end{array}$ & $61 \%$ & No & $73 \%$ & No \\
\hline $\begin{array}{l}\text { Talking with } \\
\text { friends }\end{array}$ & $47 \%$ & No & $55 \%$ & No \\
\hline Books & $46 \%$ & No & $51 \%$ & No \\
\hline $\begin{array}{l}\text { Listening to } \\
\text { experts } \\
\text { (seminars, } \\
\text { conferences) }\end{array}$ & $28 \%$ & $\begin{array}{l}\mathrm{X}^{2}(2, N=689)= \\
22.726, p=.000\end{array}$ & $27 \%$ & $\begin{array}{l}\mathrm{X}^{2}(2, N=687)= \\
10.199, p=.006\end{array}$ \\
\hline $\begin{array}{l}\text { Through social } \\
\text { media }\end{array}$ & $24 \%$ & $\begin{array}{l}\mathrm{X}^{2}(2, N=688)= \\
6.919, p=.031\end{array}$ & $33 \%$ & $\begin{array}{l}\mathrm{X}^{2}(2, N=687)= \\
18.432, p=.000\end{array}$ \\
\hline $\begin{array}{l}\text { Newspapers \& } \\
\text { magazines }\end{array}$ & $24 \%$ & $\begin{array}{l}\mathrm{X}^{2}(2, N=688)= \\
6.627, p=.036\end{array}$ & $25 \%$ & $\begin{array}{l}\mathrm{X}^{2}(2, N=687)= \\
7.980, p=.019\end{array}$ \\
\hline TV & $19 \%$ & $\begin{array}{l}\mathrm{X}^{2}(2, N=689)= \\
6.384, p=.041\end{array}$ & $32 \%$ & $\begin{array}{l}\mathrm{X}^{2}(2, N=687)= \\
7.710, p=.021\end{array}$ \\
\hline Through family & $19 \%$ & $\begin{array}{l}\mathrm{X}^{2}(2, N=688)= \\
15.103, p=.001\end{array}$ & $27 \%$ & $\begin{array}{l}\mathrm{X}^{2}(2, N=687)= \\
10.689, p=.005\end{array}$ \\
\hline
\end{tabular}

However, there were significant differences among the three groups in the other methods the participants reported using for informal learning. These included listening to experts, reading newspapers and magazines, watching television or talking to family members. When post hoc pairwise comparisons were conducted using Bonferroni-adjusted critical $P$ value of .0167 , the overall chi-square significant results primarily came from differences between the first-year group and the other two groups (see Tables 2 \& 3 ). The Bonferroni correction was used to adjust the $p$ value so as to reduce the chance of incorrectly rejecting a null hypothesis when multiple pairwise comparisons were conducted (see McDonald, 2014, for a further explanation of the Bonferroni correction). Proportionally more of the first-year students used social media for their personal development compared to the other two groups, and they used informal learning to enhance their formal studies through talking with family members. More postgraduate students reported that they used seminars and conferences as a source of informal learning to augment their formal studies than the other two groups. It should be noted, however, that the effect sizes were small $(\varnothing<.3)$. Table 3 also shows no significant differences between the undergraduate and postgraduate students in the methods they used for undertaking informal learning for their personal development. 
Table 2

Post hoc group comparisons of informal learning methods to enhance university/school work

\begin{tabular}{llll}
\hline & $\begin{array}{l}\text { Difference between FY } \\
\text { \& UG }\end{array}$ & $\begin{array}{l}\text { Difference between FY } \\
\text { \& PG }\end{array}$ & $\begin{array}{l}\text { Difference between UG } \\
\text { \& PG }\end{array}$ \\
\hline $\begin{array}{l}\text { Listening to experts } \\
\text { (seminars, }\end{array}$ & No & $\begin{array}{l}\mathrm{X}^{2}(1, N=324)=19.130, \\
p=.000 ; \varnothing=.243\end{array}$ & $\begin{array}{l}\mathrm{X}^{2}(1, N=475)=18.064, \\
p=.000 ; \varnothing=.195\end{array}$ \\
$\begin{array}{l}\text { conferences) } \\
\begin{array}{l}\text { Through social } \\
\text { media }\end{array}\end{array}$ & No & No & No \\
$\begin{array}{l}\text { Newspapers \& } \\
\text { magazines }\end{array}$ & No & No & $\mathrm{X}^{2}(1, N=475)=6.132$, \\
$\begin{array}{l}\text { TV } \\
\begin{array}{l}\text { Through parents or } \\
\text { siblings }\end{array}\end{array}$ & $\begin{array}{l}\text { No } \\
\mathrm{X}^{2}(1, N=578)=10.727,\end{array}$ & $\begin{array}{l}\text { No } \\
\mathrm{X}^{2}(1, N=323)=9.848, \\
p=.001 ; \varnothing=-.135\end{array}$ & $\begin{array}{l}\text { No } \\
p=.002 ; \varnothing=-.175\end{array}$ \\
\hline
\end{tabular}

Table 3

Post hoc group comparisons of informal learning methods to enhance personal development

\begin{tabular}{|c|c|c|c|}
\hline & $\begin{array}{l}\text { Difference between FY } \\
\text { \& UG }\end{array}$ & $\begin{array}{l}\text { Difference between FY } \\
\text { \& PG }\end{array}$ & $\begin{array}{l}\text { Difference between UG } \\
\text { \& PG }\end{array}$ \\
\hline $\begin{array}{l}\text { Listening to experts } \\
\text { (seminars, } \\
\text { conferences) }\end{array}$ & No & $\begin{array}{l}\mathrm{X}^{2}(1, N=323)=9.825 \\
p=.002 ; \varnothing=.174\end{array}$ & No \\
\hline Through social media & $\begin{array}{l}\mathrm{X}^{2}(1, N=577)=11.407 \\
p=.001 ; \varnothing=-.141\end{array}$ & $\begin{array}{l}\mathrm{X}^{2}(1, N=323)=14.587 \\
p=.000 ; \varnothing=-.213\end{array}$ & No \\
\hline $\begin{array}{l}\text { Newspapers \& } \\
\text { magazines }\end{array}$ & No & No & No \\
\hline TV & No & No & No \\
\hline $\begin{array}{l}\text { Through parents or } \\
\text { siblings }\end{array}$ & No & No & No \\
\hline
\end{tabular}

The interview accounts of how participants went about informal learning were consistent with those of the questionnaire participants. All the interview participants stated that the Internet was the tool they used most often for informal learning. However, 27 of the 30 participants also reported using more traditional tools, such as talking to people, reading books, going to the library, listening to the radio and watching television and documentaries. For instance, PG2 reported that he listened to radio broadcasts in te Reo to learn Māori language, while PG8 also engaged in informal learning through interacting with Māori people.

I've had things passed on through conversations and through going for a walk, or making a meal or sharing a meal or having a conversation while we gather some kai [Māori word for food] to have a feed, so there's been all sorts of depths of knowledge and information passed on through trust that I would have expected, and well it's relevant to my research. (PG8)

Three postgraduate students said that they undertook informal learning through having conversations with friends, classmates and other postgraduate students, which helped them with their formal research. For instance:

For post-grads ... we constantly knock on each other's doors and go "can you help with this”, it's basically ... to learn from others, you have to be open to that learning process as part of being a post-grad and part of being in a community of post-grads. (PG1)

Watching television shows and documentaries was also a means through which five interview participants engaged in informal learning. For instance, "I used to watch a lot of documentaries on like lots of things like biology, and certain things would connect over like certain facts about cells, or I learned about protein synthesis in year 11 or something like that”. (FY2) 


\section{Using digital and mobile technologies for informal learning}

The final research question focused on gaining information on which digital and mobile technologies the participants used to support their informal learning. Firstly, however, the questionnaire participants were asked to rate a number of statements on a Likert-type scale, which would provide information on their digital learning characteristics. Their responses were then compared across the three participant groups.

An instrument to measure digital learner characteristics was developed by Bullen et al. (2011), which has been used in a previous study by the first author (see Lai \& Hong, 2014). In this study, however, we use ten items from Bullen et al.’s (2011) instrument and 13 additional items developed by the authors so as to improve content validity of the instrument. A reliability index was computed, and the Cronbach's alpha was .714, highlighting how the items in the instrument had adequate internal consistency (Nunnally \& Bernstein, 1994). This instrument has ten dimensions: digital literacy, connectedness, multitasking, experiential learning, social, structure and goal-orientedness, community mindedness, need for immediacy, preference for visual information, and critical thinking; responses were solicited on a 4-point Likert-type scale (strongly agree to strongly disagree). This 4-point Likert scale was considered an ordinal scale (Jamieson, 2004), and thus the Kruskal-Wallis' (1952) rank-based nonparametric test (which means, it does not assume a normal distribution of the data) was used (instead of ANOVA) to determine whether there were any differences among the three groups in these 23 items (see McDonald, 2014, for a further definition of the Kruskal-Wallis test).

Using the Kruskal-Wallis test, it was found that there were significant differences among the three groups in ten items. Post hoc pairwise comparisons were conducted and the results are presented in Table 4. Although there were significant differences between groups in several digital learner characteristics, it was found that based on Cohen (1988), the effect sizes were small $(r<03$.), showing that there were little practical differences among the three groups in terms of digital learner characteristics.

Table 4

The participants' digital learning characteristics, with percentages of strongly agree and agree

\begin{tabular}{|c|c|c|c|c|c|c|}
\hline & $n$ & $\begin{array}{l}\text { FY } \\
(\%)\end{array}$ & $\begin{array}{l}\text { UG } \\
(\%)\end{array}$ & $\begin{array}{l}\text { PG } \\
(\%)\end{array}$ & $\begin{array}{l}\text { Kruskal-Wallis } \\
\text { test }\end{array}$ & $\begin{array}{l}\text { Group } \\
\text { differences }\end{array}$ \\
\hline $\begin{array}{l}\text { Digital literacy: } \\
\text { I am comfortable using computers, } \\
\text { the Internet and other information } \\
\text { and communication for a variety of } \\
\text { purposes. }\end{array}$ & 768 & 97.9 & 98.3 & 100 & $\begin{array}{l}\mathrm{X} 2(2)=9.531 \\
p=.009\end{array}$ & $\begin{array}{l}\text { FY \& UG } \\
\text { X2(1) = 2.998; } \\
\text { adjusted } p=.008 ; \\
r=.12\end{array}$ \\
\hline $\begin{array}{l}\text { I prefer reading from printed texts } \\
\text { than from the computer screen. }\end{array}$ & 762 & 82.0 & 81.2 & 83.2 & $\begin{array}{l}\mathrm{X} 2(2)=3.559 \\
p=.169\end{array}$ & No \\
\hline $\begin{array}{l}\text { I prefer accessing information from } \\
\text { non-printed, digital sources. }\end{array}$ & 757 & 56.4 & 47.8 & 50.4 & $\begin{array}{l}\mathrm{X} 2(2)=2.672 \\
p=.263\end{array}$ & No \\
\hline $\begin{array}{l}\text { Connectedness: } \\
\text { I feel like I am always connected to } \\
\text { friends because of technologies such } \\
\text { as cell phones and the Internet. }\end{array}$ & 767 & 95.8 & 95.9 & 86.7 & $\begin{array}{l}\mathrm{X} 2(2)=7.955 \\
p=.019\end{array}$ & $\begin{array}{l}\text { UG \& PG } \\
\text { X2(1) =-2.811; } \\
\text { adjusted } p=.015 ; \\
r=.12\end{array}$ \\
\hline I can live without a mobile phone. & 761 & 55.5 & 65.7 & 64.3 & $\begin{array}{l}\mathrm{X} 2(2)=5.547 \\
p=.062\end{array}$ & No \\
\hline $\begin{array}{l}\text { Multitasking: } \\
\text { I am used to doing several different } \\
\text { tasks at the same time. }\end{array}$ & 765 & 85.8 & 92.4 & 88.8 & $\begin{array}{l}\mathrm{X} 2(2)=11.827 \\
p=.003\end{array}$ & $\begin{array}{l}\text { FY \& UG } \\
\text { X2(1) }=3.432 ; \\
\text { adjusted } p=.002 ; \\
r=.13\end{array}$ \\
\hline $\begin{array}{l}\text { Experiential learning: } \\
\text { I prefer to learn by exploring and } \\
\text { trying things out for myself. }\end{array}$ & 762 & 83.2 & 91.6 & 92.9 & $\begin{array}{l}X 2(2)=28.843 \\
p=.000\end{array}$ & $\begin{array}{l}\text { FY \& UG } \\
\text { X2(1) = 4.177; } \\
\text { adjusted } p=.000 ; \\
r=.16 \\
\text { FY \& PG } \\
\text { X2(1) }=4.895 ; \\
\text { adjusted } p=.000 ; \\
r=.26\end{array}$ \\
\hline
\end{tabular}




\begin{tabular}{|c|c|c|c|c|c|c|}
\hline $\begin{array}{l}\text { I read the manual when learning how } \\
\text { to operate a new digital device. }\end{array}$ & 764 & 36.0 & 40.6 & 46.0 & $\begin{array}{l}\mathrm{X} 2(2)=3.749 \\
p=.153\end{array}$ & No \\
\hline $\begin{array}{l}\text { I prefer learning that is instantly } \\
\text { useful. }\end{array}$ & 755 & 81.4 & 77.2 & 72.7 & $\begin{array}{l}\mathrm{X} 2(2)=4.118 \\
p=.128\end{array}$ & No \\
\hline $\begin{array}{l}\text { Social: } \\
\text { I enjoy talking about myself to } \\
\text { people I meet. }\end{array}$ & 759 & 58.8 & 52.3 & 58.1 & $\begin{array}{l}X 2(2)=1.335 \\
p=.513\end{array}$ & No \\
\hline I enjoy meeting new people. & 764 & 94.5 & 93.2 & 92.9 & $\begin{array}{l}\mathrm{X} 2(2)=2.037 \\
p=.361\end{array}$ & No \\
\hline $\begin{array}{l}\text { I frequently use social media and } \\
\text { related tools. }\end{array}$ & 763 & 89.2 & 84.8 & 73.6 & $\begin{array}{l}\mathrm{X} 2(2)=17.841 ; \\
p=.000\end{array}$ & $\begin{array}{l}\text { FY \& PG } \\
\text { X2(1) = -3.792; } \\
\text { adjusted } p=.000 ; \\
r=.20 \\
\text { UG \& PG } \\
\text { X2(1) }=-4.050 ; \\
\text { adjusted } p=.000 ; \\
r=.18\end{array}$ \\
\hline $\begin{array}{l}\text { I prefer to work in groups when } \\
\text { doing university/school work. }\end{array}$ & 762 & 59.3 & 43.3 & 34.2 & $\begin{array}{l}X 2(2)=28.004 \\
p=.000\end{array}$ & $\begin{array}{l}\text { FY \& UG } \\
\text { X2(1) = -4.596; } \\
\text { adjusted } p=.000 ; \\
r=.18 \\
\text { FY \& PG } \\
\text { X2(1) }=-4.408 ; \\
\text { adjusted } p=.000 ; \\
r=.24\end{array}$ \\
\hline $\begin{array}{l}\text { Structure and goal-orientedness: } \\
\text { I prefer to get clear instructions and } \\
\text { information before I try something } \\
\text { new. }\end{array}$ & 766 & 91.6 & 85.2 & 79.9 & $\begin{array}{l}\mathrm{X} 2(2)=16.282 \\
p=.000\end{array}$ & $\begin{array}{l}\text { FY \& UG } \\
\text { X2(1) =-2.953; } \\
\text { adjusted } p= \\
.003) ; r=.16 \\
\text { FY\& PG } \\
\text { X2(1) = -3.784; } \\
\text { adjusted } p=.000 ; \\
r=.20\end{array}$ \\
\hline $\begin{array}{l}\text { I prefer hyperlinked information } \\
\text { than sequential information. }\end{array}$ & 764 & 37.5 & 45.8 & 49.1 & $\begin{array}{l}\mathrm{X} 2(2)=6.183 \\
p=.045\end{array}$ & No \\
\hline $\begin{array}{l}\text { I like to plan and organise my daily } \\
\text { life. }\end{array}$ & 759 & 81.8 & 79.9 & 83.2 & $\begin{array}{l}\mathrm{X} 2(2)=3.590 \\
p=.166\end{array}$ & No \\
\hline I have clear goals in life. & 761 & 81.8 & 76.7 & 80.3 & $\begin{array}{l}X 2(2)=2.121 \\
p=.346\end{array}$ & No \\
\hline $\begin{array}{l}\text { Community mindedness: } \\
\text { I get involved in projects and } \\
\text { activities that make a difference to } \\
\text { society. }\end{array}$ & 765 & 78.3 & 68.6 & 69.6 & $\begin{array}{l}\mathrm{X} 2(2)=6.395 \\
p=.041\end{array}$ & $\begin{array}{l}\text { FY \& PG } \\
\text { X2(1) }=-2.459 ; \\
\text { adjusted } p=.042 ; \\
r=.13\end{array}$ \\
\hline $\begin{array}{l}\text { Need for immediacy: } \\
\text { I seek immediate results when I } \\
\text { search the Internet for information. }\end{array}$ & 765 & 92.4 & 92.3 & 89.4 & $\begin{array}{l}\mathrm{X} 2(2)=2.452 \\
p=.294\end{array}$ & No \\
\hline $\begin{array}{l}\text { I seek immediate responses to my } \\
\text { questions. }\end{array}$ & 757 & 89.0 & 82.4 & 76.6 & $\begin{array}{l}X 2(2)=14.243 \\
p=.001\end{array}$ & $\begin{array}{l}\text { FY \& PG } \\
\text { X2(1) = -3.768; } \\
\text { adjusted } p=.000 ; \\
r=.20 \\
\text { UG \& PG } \\
\text { X2(1) }=-2.901 ; \\
\text { adjusted } p=.011 ; \\
r=.13\end{array}$ \\
\hline
\end{tabular}




\begin{tabular}{|c|c|c|c|c|c|c|}
\hline $\begin{array}{l}\text { I want instant access to my } \\
\text { friends/service. }\end{array}$ & 757 & 91.9 & 81.2 & 72.3 & $\begin{array}{l}X 2(2)=22.381 \\
p=.000\end{array}$ & $\begin{array}{l}\text { FY \& UG } \\
\text { X2 }(1)=-2.503 ; \\
\text { adjusted } p=.037 ; \\
r=.11 \\
\text { FY \& PG } \\
\text { X2(1) }=-4.713 ; \\
\text { adjusted } p=.000 ; \\
r=.25 \\
\text { UG\& PG } \\
\text { X2(1) }=-3.155 ; \\
\text { adjusted } p=.005 ; \\
r=.14\end{array}$ \\
\hline $\begin{array}{l}\text { Preference for visual information: } \\
\text { I feel that multimedia content has } \\
\text { higher value than mere text. }\end{array}$ & 755 & 51.3 & 47.4 & 42.8 & $\begin{array}{l}\mathrm{X} 2(2)=1.885 \\
p=.390\end{array}$ & No \\
\hline $\begin{array}{l}\text { Critical thinking: } \\
\text { I compare several Internet sources to } \\
\text { find the most reliable information. }\end{array}$ & 766 & 83.3 & 83.3 & 85.8 & $\begin{array}{l}\mathrm{X} 2(2)=1.236 \\
p=.539\end{array}$ & No \\
\hline
\end{tabular}

We also wondered if the three groups of participants would use similar digital and mobile learning devices and applications in their informal learning. The questionnaire participants were given a list of digital devices and applications and were asked to indicate how often they had used them to support their informal learning on a 5-point Likert-type scale (almost always to never). A total of 89\% of the participants reported that they almost always or often used laptop or notebook computers to facilitate their informal learning, while 48\% stated they used desktop computers. Approximately half (52\%) of the participants said they almost always or often used mobile phones, but only $19 \%$ reported using tablet computers (e.g., iPad) for informal learning. Google was the most utilised application, with $90 \%$ of the questionnaire participants stating they almost always and often used it for informal learning, which was followed by other websites (89\%), emailing (65\%), wikis (51\%), Google Scholar (42\%) and podcasts (18\%). The most popular communication tool was texting (38\%) and Skype (20\%). Few participants tweeted $(9 \%)$, blogged $(13 \%)$ or participated in online discussion groups $(12 \%)$, while the 3D online virtual world Second Life (6\%) was the least used application the participants used to support informal learning.

Using the Kruskal-Wallis test, it was found that there were significant differences among the three groups in the use of all four digital and mobile devices, and pairwise comparisons showed that there were significant differences between most groups (see Table 5). However, the effect sizes were small ( $r$ equals or is less than .2), meaning that there were little practical significant differences between the groups in terms of the proportions of the participants using these devices. In terms of the four most popular applications used by the participants, no significant differences were found.

The interview participants also discussed the digital devices and applications they used to support their informal learning. They reported that Wikipedia was the most popular application used to search for information on the Internet (12 participants), which was followed closely by Google (11 participants). For instance, PG12 said, "I mean Wikipedia is always easy ... for when we do research we look up atomic weight or anything like and that info, that's one place particular otherwise ... you have to go to books". UG2 also said "When I'm reading I Google words that I don't know. I put them in a big list 'cause it takes a while to Google each individual one”. Eight students also used YouTube as an information source. For instance, UG 11 said, "I'm trying to use informal learning to gain an inside into my formal learning and retrieving YouTube videos and things like that, which I find really helpful”. Eight participants also used social networking sites as sources of informal learning. For instance, UG 11 commented, "If you're social networking ... like that you can form socially to discuss things ... so a simultaneous way, is in a way being with a whole lot of people who are interested in the same areas”. 
Table 5

Group differences in using digital and mobile devices and applications to support informal learning

\begin{tabular}{|c|c|c|c|c|}
\hline & $\begin{array}{l}\text { Kruskal-Wallis } \\
\text { test for group } \\
\text { differences }\end{array}$ & $\begin{array}{c}\text { Difference } \\
\text { between FY \& UG }\end{array}$ & $\begin{array}{c}\text { Difference } \\
\text { between FY \& PG }\end{array}$ & $\begin{array}{c}\text { Difference } \\
\text { between UG \& PG }\end{array}$ \\
\hline $\begin{array}{l}\text { Laptop or } \\
\text { notebook } \\
\text { computer }\end{array}$ & $\begin{array}{l}X^{2}(2)=14.857 ; p \\
=0.001\end{array}$ & $\begin{array}{l}\mathrm{X}^{2}(2)=3.422 ; \\
\text { adjusted } p=0.002 \\
r=0.14\end{array}$ & No & $\begin{array}{l}\mathrm{X}^{2}(2)=-2.657 \\
\text { adjusted } p=0.024 ; \\
r=0.12\end{array}$ \\
\hline Mobile phone & $\begin{array}{l}\mathrm{X}^{2}(2)=12.925 ; p \\
=0.002\end{array}$ & $\begin{array}{l}\mathrm{X}^{2}(2)=-2.427 \\
\text { adjusted } p=0.046 \\
r=0.10\end{array}$ & $\begin{array}{l}\mathrm{X}^{2}(2)=-3.441 ; \\
\text { adjusted } p=0.002 ; \\
r=0.19\end{array}$ & No \\
\hline $\begin{array}{l}\text { Desktop } \\
\text { computer }\end{array}$ & $\begin{array}{l}X^{2}(2)=26.482 ; p \\
=0.002\end{array}$ & $\begin{array}{l}\mathrm{X}^{2}(2)=-4.476 ; \\
\text { adjusted } p=0.000 ; \\
r=0.19\end{array}$ & No & $\begin{array}{l}\mathrm{X}^{2}(2)=3.721 ; \\
\text { adjusted } p=0.001 ; \\
r=0.17\end{array}$ \\
\hline Tablet & $\begin{array}{l}\mathrm{X}^{2}(2, \mathrm{~N}=766)= \\
20.038, p=.000\end{array}$ & $\begin{array}{l}\mathrm{X}^{2}(2)=4.441 ; \\
\text { adjusted } p=0.000 ; \\
r=0.20\end{array}$ & $\begin{array}{l}\mathrm{X}^{2}(2)=-2.399 \\
\text { adjusted } p=0.049 \\
r=0.14\end{array}$ & No \\
\hline Email & No & No & No & No \\
\hline Websites & No & No & No & No \\
\hline Google & No & No & No & No \\
\hline Wiki & No & No & No & No \\
\hline
\end{tabular}

Most of the postgraduate interview participants reported using desktop or laptop computers (eight participants), rather than mobile phones (four participants) to search for information on the Internet. In contrast 11 of the 12 undergraduates reported using their mobile phones, eight their laptops and two desktop computers when searching for information. Three first-year participants reported using their laptops, two desktop computers and one a smartphone to search for information.

Three of the postgraduate interview participants, one undergraduate and one first-year participant also stated that they were not very proficient in using digital and mobile technologies. For instance, when she was asked if she thought she was a competent user of digital and mobile technologies, PG11 said:

I don't think so in nowadays the technology is ... a lot of new technologies to me I think maybe for some field I am good at. For example, I think I good at searching for information on the Internet ... and some new technology such as iPhone, iPad (laughs) I do not use very much, so I think I not good at all these functions.

Over $80 \%$ of the questionnaire participants reported that they preferred reading from printed texts than computer screens (see Table 4). Three interview participants also discussed the difficulty of accessing information online and reading texts from computer screens. For example:

I can sort of look at things on my phone, but I generally find it quite limited 'cause the screen's smaller and browsing isn't very clean ... it's sort of hard to navigate you know, on a computer it's so easy to open up twenty different apps and read all [on] the screen, so it's quite easy to absorb information on the big screen, but on a smaller screen you sort of spend as much time zooming around on the page trying [to] read passages. (UG5)

The overwhelming majority of questionnaire participants (92\%) and interview participants (28 from 30) reported that they had engaged in informal learning in the past year. Of the questionnaire participants, $70 \%$ stated that they engaged in informal learning for their personal development and to support their formal coursework. The most common form of technology used by the participants to support their informal learning was laptops, which was followed by desktop computers. The participants primarily engaged in informal learning through accessing the Internet and searching for information via Google or Wikipedia, but they also engaged in informal learning through more traditional means, such as reading books, talking with friends or visiting the library. Furthermore, the overwhelming majority of interview participants (28 from 30) drew on the traditional notions of informal learning as being done in one's own time, outside of formal coursework requirements without the direction of a teacher, while few (five) framed the relationship between informal and formal learning as symbiotic. 


\section{Discussion and conclusion}

The undergraduate and first-year interview participants framed the relationship between informal and formal learning as functional that is, they reported that they engaged in informal learning primarily to support their formal coursework. However, the postgraduate participants made arbitrary links between their informal learning and formal learning. For example, the postgraduate participants explained that they undertook informal learning for "time out" from formal study, rather than to enhance their formal coursework. Although we cannot be certain why this was the case we propose two possible explanations. Postgraduate students work independently and are responsible for guiding their own study with the support of a supervisor. By contrast, first-year and undergraduate students are taught prescribed content by their teachers. Consequently, the postgraduate students may have been less likely to link informal learning to their formal course of study because the two forms of learning are not as bounded as they are at the undergraduate level.

Furthermore, as undergraduate and first-year students are generally younger than postgraduate students, they are more likely to have grown up immersed in neo-liberal ideology. Although we did not collect information on the participants' ages, a number of the postgraduate interviewees discussed their previous careers and/or high school aged children. Consequently, the first-year and undergraduate students may have been more likely to report engaging in informal learning to support their formal learning because unlike postgraduate students, they may have been bought up inculcated in neo-liberal ideology, which ties educational success to a successful life path (Harris, 2004).

Moreover, despite laptops being the most favoured digital technology used to search for information, which was followed by desktop computers, results of the questionnaire show that the majority of participants (average $82.1 \%$ across the three groups) preferred reading printed texts to reading from computer screens. Five of the 30 interview participants also reported that they preferred reading information from printed texts rather than from computer screens. Such results highlight that, despite the ubiquity of digital mobile device ownership, this does not necessarily mean students enjoy or prefer reading from computer screens to reading from printed texts. Furthermore, all groups reported that they facilitated their informal learning through more traditional means, such as conversing with peers, reading books, visiting libraries, watching television or documentaries and listening to the radio. This highlights how traditional means of obtaining information and learning have not been usurped by the increasing popularity of digital and mobile technologies. Therefore, we suggest that if university teachers are to incorporate mobile and digital devices in their formal courses, then they must do so in conjunction with more traditional methods of accessing information and learning, rather than prioritising one form of learning over another. In this way, teachers can cater for the diverse learning styles of students.

When it came to using social media in their informal learning, the first-year student questionnaire participants reported using these applications the most, while postgraduate students were more likely to engage in informal learning through attending seminars and lecturers than the other two participant groups (see Table 1). Interestingly, the majority of postgraduate questionnaire participants (65.8\%) and undergraduate questionnaire participants (56.7\%) reported that they preferred not to do group work as part of their formal coursework, while 59.3\% of the first-year students preferred group work to independent work. Such results show that the group learning opportunities provided by social networking sites such as Facebook may not necessarily be welcomed by students themselves if introduced into formal coursework, which supports previous research findings (Dahlstrom et al., 2013; Selwyn, 2013). Consequently, we suggest that lecturers should only introduce social networking sites into their courses for the purposes of grouping students or to allow students to share information amongst themselves, and not as part of the formal requirements of their courses.

Many participants' comments showed how they valued the self-directedness of their informal learning compared to the teacher directedness of their formal learning. The ability to learn independently is highly valued in a knowledge society, and therefore a pedagogical implication of this study is that lecturers should encourage students to engage in informal learning to augment their formal studies. In order to do so, however, lecturers need to increase their own understanding of the connection between formal and informal learning. 
Although this study provides interesting findings regarding students' understandings of informal and formal learning and their usage of mobile digital technologies, the research has limitations. For instance, while the questionnaire sample was large, it was conducted at one university and it was a convenience sample. Proportionally there was also an overrepresentation of postgraduate interview participants. For these reasons, and because this article reports a case study of one New Zealand university, our findings cannot be generalised to other tertiary students or settings. To further develop the knowledge base of this field of study, more research is needed on tertiary students' informal learning and their use of digital and mobile technologies to support learning.

\section{Acknowledgements}

The authors would like to thank all the students who participated in this study. They would also like to acknowledge the funding support from the University of Otago's Teaching Development Grant. The feedback provided by the anonymous reviewers and the editors is greatly appreciated.

\section{References}

Barron, B. (2006). Interest and self-sustained learning as catalysts of development: A learning ecology perspective. Human Development, 49(4), 193-224. doi:10.1159/000094368

Bonk, C. (2012, February). Plenary talk: Technology enhanced learning: From tinkering to tottering to totally extreme learning. Presentation to the 1st International Conference on Open and Distance Learning, Manila. Retrieved from http://trainingshare.com/pdfs/Curt_Bonk_Extreme_Learning_Philippines_Conference--Citation.pdf

Bosman, J. P., \& Strydom, S. (2016). Mobile technologies for learning: Exploring critical mobile learning literacies as enabler of graduateness in a South African research-led University. British Journal of Educational Technology, 47(3), 510-519. doi:10.1111/bjet.12441

Boustedt, J., Eckerdal, A., McCartney, R., Sanders, K., Thomas, L., \& Zander, C. (2011). Students’ perceptions of the differences between formal and informal learning. In Proceedings of the Seventh International Workshop on Computing Education Research (pp. 61-68). New York, NY: ACM. doi:10.1145/2016911.2016926

Bull, G., Thompson, A., Searson, M., Garofalo, J., Park, J., Young, L., \& Lee, J. (2008). Connecting informal and formal learning experiences in the age of participatory media. Contemporary Issues in Technology and Teacher Education, 8(2), 100-107. Retrieved from https://citejournal.s3.amazonaws.com/wp-content/uploads/2016/04/v8i2editorial1.pdf

Bullen, M., Morgan, T., \& Qayyum, A. (2011). Digital learners in higher education: Generation is not the issue. Canadian Journal of Learning \& Technology, 37(1), 1-24. doi:10.21432/T2NC7B

Clough, G., Jones, A., McAndrew, P., \& Scanlon, E. (2009). Informal learning in online communities of mobile devices enthusiasts. In M. Ally (Ed.), Mobile learning: Transforming the delivery of education and training (pp. 100-112). Athabasca: Athabasca University Press.

Cohen, J. (1988). Statistical power analysis for the behavioral sciences. Hillsdale, NJ: Erlbaum.

Crook, C. (2012). The 'digital native' in context: Tensions associated with importing Web 2.0 practices into the school setting. Oxford Review of Education, 38(1), 63-80. doi:10.1080/03054985.2011.577946

Cross, J. (2007). Informal learning: Rediscovering the natural pathways that inspire innovation and performance. San Francisco, CA: Pfeiffer.

Dabbagh, N., \& Kitsantas, A. (2012). Personal learning environments, social media, and self-regulated learning: A natural formula for connecting formal and informal learning. Internet and Higher Education, 15(1), 3-8. doi:10.1016/j.iheduc.2011.06.002

Dahlstrom, E., Walker, J., \& Dziuban, C. (2013). ECAR study of undergraduate students and information technology, 2013. Retrieved from https://net.educause.edu/ir/library/pdf/ers1302/ers1302.pdf

Furlong, J., \& Davies, C. (2012). Young people, new technologies and learning at home: Taking context seriously. Oxford Review of Education, 38(1), 45-62. doi:10.1080/03054985.2011.577944

Greenhow, C., \& Robelia, B. (2009). Informal learning and identity formation in online social networks. Learning, Media \& Technology, 34(2), 119-140. doi:10.1080/17439880902923580

Hall, R. (2009). Towards a fusion of formal and informal learning environments: The impact of the $\mathrm{read} /$ write web. Electronic Journal of E-Learning, 7(1), 29-40. Retrieved from http://www.ejel.org/volume7/issue1

Harris, A. (2004). Future girl: Young women in the twenty-first century. London: Routledge. 
Humpage, L. (2015). Policy changes, public attitudes and social citizenship: Does neo-liberalism matter? Bristol: Policy Press.

Jamieson, S. (2004). Likert scales: How to (ab)use them. Medical Education, 38, 1212-1218. doi:10.1111/j.1365-2929.2004.02012.x

Khaddage, F., Christensen, R., Lai. K. W., Knezek, G., Norris, C., \& Soloway, E. (2015). A model driven framework to address challenges in a mobile learning environment. Education and Information Technologies, 20(4), 625-640. doi:10.1007/s10639-015-9400-X

Kruskal, W. H., \& Wallis, W. A. (1952). Use of ranks in one-criterion variance analysis. Journal of the American Statistical Association, 47(260), 583-621. doi:10.2307/2280779

Lai, K. W., \& Hong, K. S. (2014). Technology use and learning characteristics of students in higher education: Do generational differences exist? British Journal of Educational Technology, 46(4), 725738. doi:10.1111/bjet.12161

Lai, K. W., Khaddage, F., \& Knezek, G. (2013). Blending student technology experiences in formal and informal learning. Journal of Computer Assisted Learning, 29(5), 414-425. doi:10.1111/jcal.12030

Livingstone, D. W. (2009). Basic research on lifelong learning: Recent survey findings and Reflections on “capturing” informal learning. In G. Vavoula, N. Pachler, \& A. Kukulska-Hulme (Eds.), Researching mobile learning: Frameworks, tools and research designs (pp. 41-60). Bern: Peter Lang.

Maykut, P., \& Morehouse, R. (1994). Beginning qualitative research: A philosophic and practical guide. London: Falmer Press.

McDonald, J. H. (2014). Handbook of biological statistics (3rd ed.). Baltimore, MD: Sparky House Publishing.

Mills, L. A., Knezek, G., \& Khaddage, F. (2014). Information seeking, informal sharing, and going mobile: Three bridges to informal learning. Computers in Human Behavior, 32, 324-334. doi:10.1016/j.chb.2013.08.008

Ministry of Social Development. (n.d). Studylink: Hoto Akoranga. Retrieved from https://www.studylink.govt.nz/

Nunnally, J. C., \& Bernstein, I. H. (1994). Psychometric theory (3rd ed.). New York, NY: McGraw-Hill.

Organisation for Economic Co-operation and Development. (n.d). Education at a glance, 2013. Retrieved from https://www.oecd.org/edu/New Zealand_EAG2013 Country Note.pdf

Rohs, M. (2008). Informal e-learning: What does it mean? In P. A. Bruck \& M. Lindner (Eds.), Microlearning and Capacity Building: Proceedings of the 4th International Microlearning 2008 Conference (pp. 24-36). Innsbruck: Innsbruck University Press.

Sefton-Green, J. (2004). Literature review in informal learning with technology outside school. Retrieved from https://www.nfer.ac.uk/publications/FUTL72/FUTL72.pdf

Selwyn, N. (2011). Social media in higher education. Retrieved from http://www.educationarena.com/pdf/sample/sample-essay-selwyn.pdf

Small, D. (2009, November). Neoliberalism's fate: Implications for education. Paper presented at the 37th Annual Conference of ANZCIES, University of New England, Armidale, Australia. Retrieved from https://ir.canterbury.ac.nz/handle/10092/4719

Song, D., \& Lee, J. (2014). Has Web 2.0 revitalized informal learning? The relationship between Web 2.0 and informal learning. Journal of Computer Assisted Learning, 30, 511-533.

doi:10.1111/jcal.12056

Corresponding author: Kwok-Wing Lai, wing.lai@otago.ac.nz

Australasian Journal of Educational Technology (c) 2017.

Please cite as: Lai, K.-W., \& Smith, L. A. (2017). Tertiary students' understandings and practices of informal learning: A New Zealand case study. Australasian Journal of Educational Technology, 33(2), 115-128. https://doi.org/10.14742/ajet.2937 